\title{
Isolation of Pseudomonas with the Ability to Solublize Phosphate from Inorganic and Organic Phosphate Sources
}

\author{
Lamenew Fenta ${ }^{1}$, Fassil Assefa ${ }^{2}$ \\ ${ }^{1}$ Department of Biology, Assosa University, Assosa, Ethiopia \\ ${ }^{2}$ Department of Microbial, Cellular and Molecular Biology, Addis Ababa University, Addis Ababa, Ethiopia
}

Email address:

lamefent21@gmail.com (L. Fenta)

\section{To cite this article:}

Lamenew Fenta, Fassil Assefa. Isolation of Pseudomonas with the Ability to Solublize Phosphate from Inorganic and Organic Phosphate Sources. International Journal of Microbiology and Biotechnology. Vol. 4, No. 3, 2019, pp. 87-93. doi: 10.11648/j.ijmb.20190403.14

Received: July 2, 2019; Accepted: July 26, 2019; Published: September 5, 2019

\begin{abstract}
A total of eleven phosphate solubilizing bacteria were isolated from rhizosphere soil of tomato (Solanum lycopersicum) plants. Isolates designated as PSB1, PSB2, PSB4, PSB5 and PSB7 were selected out of eleven isolates based on their clear zone diameters. They were characterized to generic level and found to belong to Pseudomonas spp. Tricalcium phosphate (TCP), rock phosphate (RP) and bone phosphate (BP) solubilizing efficiency of these isolates was studied in the laboratory at 5, 10, and 15 days of incubation. All bacterial isolates solubilized significantly $(\mathrm{P}<0.05)$ higher amounts of TCP over uninoculated control. The highest $\mathrm{P}$ was release upon 5 days of incubation was recorded from the isolate PSB1 with 7.64 $\mathrm{mg} / 50 \mathrm{ml}$ in the medium and the least P release was recorded by isolates PSB4 and PSB5 with a P content of $4.79 \mathrm{mg} / 50 \mathrm{ml}$. At 10th day of incubation, the highest P release was recorded by isolates PSB2 $(8.19 \mathrm{mg} / 50 \mathrm{ml})$, PSB1 $(8.10 \mathrm{mg} / 50 \mathrm{ml})$. At 15 th days of incubation, the highest P release was recorded by isolate PSB7 $(11.77 \mathrm{mg} / 50 \mathrm{ml})$ and PSB2 $(11.33 \mathrm{mg} / 50 \mathrm{ml})$ and the least P released was recorded by isolate PSB5 $(5.44 \mathrm{mg} / 50 \mathrm{ml})$ ). Under RP solubilization, the p released from all isolates upon 5 days of incubation was not significant as compared to the control. At $10^{\text {th }}$ day of incubation, the highest $\mathrm{P}$ release was recorded by isolates PSB5 $(5.56 \mathrm{mg} / 50 \mathrm{ml})$, PSB7 $(5.02 \mathrm{mg} / 50 \mathrm{ml})$ and the least P release was observed by isolate PSB4 $(3.46 \mathrm{mg} / \mathrm{g})$. At $15^{\text {th }}$ days of incubation, the highest P release was recorded by isolate PSB7 $(7.928 \mathrm{mg} / 50 \mathrm{ml})$ and the least P release was recorded by isolate PSB4 $(4.025 \mathrm{mg} / 50 \mathrm{ml})$. Regarding BP, the p released from all isolates except isolate PSB7 $(3.020 \mathrm{mg} / 50 \mathrm{ml})$ upon 5 days of incubation was not significant as compared to the control. At 10th day of incubation, the highest P release was recorded by isolates PSB5 $(7.37 \mathrm{mg} / 50 \mathrm{ml})$, PSB7 $(7.025 \mathrm{mg} / 50 \mathrm{ml})$ and the least P released was observed by isolate PSB2 $(5.47 \mathrm{mg} / 50 \mathrm{ml})$. At $20^{\text {th }}$ days of incubation, the highest P release was recorded by isolate PSB7 $(11.09 \mathrm{mg} / 50 \mathrm{ml})$ and the least P release was recorded by isolate PSB4 $(9.06 \mathrm{mg} / 50 \mathrm{ml})$. So, as conclusion all Psedomonas isolates were able to release $\mathrm{P}$ from both inorganic and organic phosphate sources.
\end{abstract}

Keywords: Biofertilizers, Clear Zone, Phosphorus, Solubilization Efficiency

\section{Introduction}

Phosphorus $(\mathrm{P})$ is the major nutrient after nitrogen $(\mathrm{N})$ that limits plant growth $[1,2]$. Chemical $\mathrm{P}$ fertilizer is the main source of plan available $\mathrm{P}$ in the agriculture soils, but almost 75 to $90 \%$ of added $\mathrm{P}$ fertilizer is precipitated by iron, aluminum and calcium complexes present in the soils [1, 3]. The problems of $\mathrm{P}$ deficiency are generally alleviated through the application of $\mathrm{P}$ fertilizers by field practitioners, which they use to achieve maximum plant productivity; but this practice is expensive. The repeated and injudicious applications of chemical $\mathrm{P}$ fertilizers, however, lead to the loss of soil fertility [1] by disturbing microbial diversity, and consequently reducesyield of crops. Every season plants use only $15-20 \%$ of the fertilizer input. The rest is fixed (sorbed) in the soil and use of chemical fertilizer is not sustainable in both large-scale and small-scale agriculture. Since the indiscriminate and excessive applications of chemical $P$ fertilizers cause a profound adverse effect on the sustainability of crops and safety of the soil environment, agrarian communities are desperate to find alternative strategies that could ensure competitive yields while maintaining the nutrient pool of soils. Emphasis is therefore, 
being placed onto the possibility of greater utilization of unavailable $\mathrm{P}$ forms wherein the $\mathrm{P}$-solubilizing microbes could play a pivotal role in making soluble $\mathrm{P}$ available to plants [4]. So, Manipulation of microorganisms to enhance $\mathrm{P}$ availability in the soil has is a major option. $\mathrm{P}$ solubilizing microorganisms have the ability to mineralize and solubilize $\mathrm{P}$ in the short-circuit of $\mathrm{P}$ cycle in the soil, Mineralize organic $\mathrm{P}$ with Enzyme phosphatases, Solubilize sorbed inorganic P through organic acid production. It is known that most of the $\mathrm{P}$ sources are inorganic phosphates locked in the rocks (rock phosphates), Inorganic $\mathrm{P}$ sorbed in the soil (Al, Fe, $\mathrm{Mg}$, Phosphates). So Microbes that solubilize inorganic phosphates are the most important for crop production. Microorganisms involved in the solubilization of insoluble $\mathrm{P}$ include bacteria, fungi, actinomycetes and arbuscular mycorrhizal (AM) fungi [5-7]. Therefore, the use of microbial inoculants (biofertilizers) possessing P-solubilizing activities in crop productivity is considered as an environment-friendly alternative to further applications of mineral $\mathrm{P}$ fertilizers.

The microorganisms known for $\mathrm{P}$ availability in the soil include extensive range of soil bacteria, actinomycetes, cyanobacteria and fungiThe most important members from Bacteria:Pseudomonas, Enterobacter, Bacillus, Rhizobium, the most important members from Fungi: Aspergillus, Penicillium, Trichoderma, Stimulation of different crops by PSM has been demonstrated in soybean, cheak pea, maize [8] and in canola, lettuce, and tomato [9].

In Ethiopia, several authors isolated phosphate solubilizing microorganisms (PSM). The studies $[10,11]$ showed diversity in PS among the isolatesEvaluated the $\mathrm{P}$ solubilization in vitroon solid medium. In liquid medium by measuring $\mathrm{P}$ release fromDifferent $\mathrm{P}$ sources such as Rock phosphtes (Egyptian RF, Bikillal RF, bone phosphates)Showed plant growth through inoculation of PSM of different crops. It has also been documented that different species of PSB isolated from Ethiopian soils were able to release phosphate from insoluble $\mathrm{P}$ sources such as tricalcium phosphate, hydroxyl apatite, rock phosphate and old bone [10, 12, 13]. Recently, emerging evidences indicated that, besides increased $\mathrm{P}$ uptake, the production of phytohormones such as indole acetic acid (IAA) and suppression of different soil borne phytopathogens by PSB could also play an imperative role in plant growth promotion [14-17]. Several reports demonstrated that inoculation of PSB which exhibited multiple plant growth promoting activities significantly improved plant growth and yield under glasshouse and field conditions $[16,17]$.

Intense use of P-fertilizer in the Ethiopian context is impossible for it is neither available nor affordable to the resource poor farmers which require alternatives or suppliments using microorganisms alone or co-inoculation with phosphate rocks to enhance $\mathrm{P}$ nutrition in crop production. Thus, the aim of this study was to isolate and characterize Psedomonas bacteria from tomato rhizosphere and evaluate its phosphorus release from inorganic and organic phosphate sources.

\section{Materials and Methods}

\subsection{Isolation of Phosphate Solubilizing Bacteria}

Phosphate solubilizing bacteria were isolated from collected soil samples by serial dilution plate count method using Pikovskaya medium [18] which is a selective medium for isolation of phosphate solubilizers.

Ten grams of soil from each sample was suspended in 90 $\mathrm{ml}$ of sterilized water in $250 \mathrm{ml}$ flask to make 1:10 dilution. These were agitated on a shaker for 30 minutes to break clogs. Then series of dilutions $10^{-1}, 10^{-2}, 10^{-3}, 10^{-5}$ and $10^{-6}$ were made. From dilutions of $10^{-4}, 10^{-5}$ and $10^{-6}, 0.1 \mathrm{ml}$ of suspension was transferred on Petri dish containing Pikovskaya's medium. The suspension was spread uniformly on Petri dish using glass rod spreader and incubated at $30 \pm 1^{\circ} \mathrm{C}$ for 7 days and the colonies exhibiting clear zones were selected, purified by streak plate method. The diameter of zone of solubilization was measured and expressed in centimeter and the selected isolates were preserved on agar slants for further use. The isolates were designated as PSB1, PSB2, PSB4, PSB5 and PSB7.

\subsection{Identification and Characterization of the Bacterial Isolates}

All the selected isolates were examined for the colony morphology, cell shape, and colony type.

Biochemical Characterization: The PSB isolates were further characterized using the following biochemical tests.

Fluorescent Pigment Production: King's B medium was used for this experiment [19]. Each isolate was incubated in the King's B medium and allowed to grow for 5 days. The diffusing pigment of each growth was observed using UV light at wave length of $230 \mathrm{~nm}$.

Starch hydrolysis: The ability of the isolates to hydrolyze starch was examined by the procedure of [20]. Petri plates containing starch agar were inoculated with test cultures and incubated at $30^{\circ} \mathrm{C}$ for three days. After incubation the plates were flooded with Lugol's iodine solution and allowed to stand for 15-20 minutes. The clear zone around the colony was considered as positive for the test.

Catalase test: Nutrient agar slants were inoculated with test organisms and were incubated at $30^{\circ} \mathrm{C}$ for 24 hours. After incubation the tubes were flooded with one $\mathrm{ml}$ of three per cent hydrogen peroxide and observed for production of gas bubbles. The occurrence of gas bubbles was scored positive for catalase activity [21].

Gelatin liquefaction: To the pre sterilized nutrient gelatin deep tubes, the test cultures were inoculated and tubes were incubated at $28 \pm 2^{\circ} \mathrm{C}$ for 24 hours. Following this, the tubes were kept in a refrigerator at $4^{\circ}$ for 30 minutes. The tubes with cultures that remained liquefied were taken as positive and those that solidified on refrigeration were taken as negative for the test [20].

Oxidase test: A small piece of Whatman filter paper was soaked with $1 \%$ aqueous solution of tetra methyl-pphenyldiamine dihydrochloride and a loop full of 24 hours 
old culture was scrapped and rubbed on the filter paper. The appearance of a blue color in 10-20 seconds was considered as a positive test for oxidase [22].

Methyl red and Voger - Proskauer test: $5 \mathrm{ml}$ of MRVP broth was distributed in test tubes and autoclaved at $121^{\circ} \mathrm{C}$ with a pressure of 15 psi for $15 \mathrm{~min}$. MRVP tubes were inoculated with $24 \mathrm{hr}$ old culture and incubated at $28^{\circ} \mathrm{C}$ for $2-$ 3 days. Then five drops of methyl red indicator was added to one of the tubes inoculated with each culture. The development of red color indicated a positive test. With regard to VP test 12 drops of VP 1 reagent and 2-3 drops of VP 2 reagent were added to the other test tubes. The presence of pink color was the characteristics of acetone production.

\section{Utilization of different carbon sources}

The isolates were examined for their ability to utilize different carbon sources viz, Lactose, maltose, and dextrose. The test was carried out according to the research [23]. The carbon sources were autoclaved together with the medium at $121^{\circ} \mathrm{C}$ for 15 minutes and a pressure of $15 \mathrm{psi}$. The growth was observed and recorded.

\subsection{Screening of Isolates for Phosphate Solubilization}

Quantitative Estimation of $P$ Released From Insoluble P Source

The test PSB isolates used for this experiment were PSB1, PSB2, PSB4, PSB5 and PSB7. Fifty $\mathrm{ml}$ of Pikovskaya's broth (without phosphorus source) was dispensed in $250 \mathrm{ml}$ Erlenmeyer flasks and to this $250 \mathrm{mg}$ of tricalcium phosphate,
$333.33 \mathrm{mg}$ of rock phosphate, and $200 \mathrm{mg}$ of old bone meal were separately added to each flask. The above quantities gave equivalent amount of phosphate ions. The flasks were sterilized at $121^{\circ} \mathrm{C}$ and pressure $15 \mathrm{psi}$ for 15 minutes. This autoclaved and cooled medium was inoculated with $0.1 \mathrm{ml}$ of $24 \mathrm{hrs}$ active culture of each isolates. Three replicate flasks were used for each PSB isolates and the amount of Pi released in the broth was estimated at 5, 10 and15 days after inoculation [10].

Data Analysis

The data obtained from the experiments were subjected to statistical analysis of variance (ANOVAS). Analysis was performed for all data with triplicates for each. The data groups were analyzed using the statistical Soft Ware JMP (John's Macintosh Project) in version 5.0.1 with stastical significant difference at $\left(\mathrm{p}<\_0.05\right)$.

\section{Results}

\subsection{Identification of PSB Isolates}

In this experiment a total of 11 phosphate solubilizing bacteria (PSB) isolates were isolated from tomato ( $L$. esculentum) rhizosphere. The isolates were examined for their ability to solubilize insoluble tricalcium phosphates. The selected isolates were characterized and tentatively identified up to genus level based on morphological and biochemical properties (Table 1).

Table 1. Some morphological and biochemical tests of PSBs.

\begin{tabular}{|c|c|c|c|c|c|c|}
\hline \multirow{2}{*}{\multicolumn{2}{|c|}{ Tests }} & \multicolumn{5}{|l|}{ Isolates } \\
\hline & & $\mathbf{P S B}_{1}$ & $\mathbf{P S B}_{2}$ & $\mathbf{P S B}_{4}$ & PSB $_{5}$ & $\mathbf{P S B}_{7}$ \\
\hline \multicolumn{2}{|l|}{ Shape } & rod & rod & rod & rod & Rod \\
\hline \multicolumn{2}{|l|}{ Gram reaction } & negative & negative & negative & negative & negative \\
\hline \multicolumn{2}{|l|}{ Catalase test } & + & + & + & + & + \\
\hline \multicolumn{2}{|l|}{ Oxidase test } & + & + & + & + & + \\
\hline \multicolumn{2}{|c|}{ Gelatinliquefaction test } & - & - & - & - & - \\
\hline \multicolumn{2}{|c|}{ Starchhydrolysis } & + & + & + & + & + \\
\hline \multicolumn{2}{|l|}{ Vp test } & - & - & + & - & - \\
\hline \multicolumn{2}{|c|}{ Pigment production test } & yellowish & yellowish & greenish blue & yellowish & greenish blue \\
\hline \multicolumn{2}{|l|}{ Endo spore test } & - & - & - & - & - \\
\hline \multirow{3}{*}{$\begin{array}{l}\text { Carbohydrate } \\
\text { Utilization test }\end{array}$} & lactose & + & + & + & + & + \\
\hline & Maltose & + & + & + & + & + \\
\hline & dextrose & + & + & + & + & + \\
\hline
\end{tabular}

Note: “+”: stands for positive result “"-": stands for negative result

As indicated in table 1 all isolates were rod shaped, gram negative, catalase positive, oxidase positive, gelatin negative, starch hydrolysis positive and endospore negative. Isolates PSB1, PSB5 and PSB7 were negative and isolate PSB2 and PSB4 were positive for methyl red test. Likewise, all isolates except PSB4 were positive for VP test. The result of pigment production test indicated that isolate PSB1, PSB2 and PSB5 showed yellow pigment but PSB4 and PSB7 showed greenish blue pigment. Under carbohydrate utilization test, all isolates utilized lactose, maltose and dextrose as carbon sources. Based on the above characteristics attempts were made to classify them in to their respective genera.
Accordingly the isolates were found to belong to the genera Pseudomonas.

\subsection{Phosphate Solubilization by the Isolates}

All the isolates were examined for their ability to solubilize phosphate sources on agar media supplemented with tricalcium phosphate.

Solubilization index was calculated using the formula [24]:

$$
\mathrm{SI}=\frac{\text { colony diameter }+ \text { clearing zone }}{\text { Colony diameter }}
$$


Table 2. Colony diameter, Halo zone diameter and Solubilization index of isolates upon 72 hrs of incubation.

\begin{tabular}{llll}
\hline Isolates & $\begin{array}{l}\text { Colony diameter } \\
(\mathbf{c m})\end{array}$ & $\begin{array}{l}\text { Halo zone } \\
\text { Diameter(cm) }\end{array}$ & $\begin{array}{l}\text { Solubilization } \\
\text { index (SI) }\end{array}$ \\
\hline PSB1 & 1.3 & 2.1 & 2.61 \\
PSB2 & 1.4 & 2.0 & 2.42 \\
PSB4 & 0.9 & 1.1 & 1.80 \\
PSB5 & 1.05 & 1.6 & 2.52 \\
PSB7 & 1.0 & 2.5 & 3.50 \\
\hline
\end{tabular}

Note: All values are means of triplicates.

The isolates formed colony diameter of between 0.9 and $1.4 \mathrm{~cm}$. The maximum colony diameter was showed by PSB2 (1.4) followed by PSB1 (1.3) and PSB5 (1.05). Similarly, the isolates formed a clear (halo) zone diameter of between 1.1 $\mathrm{cm}$ and $2.5 \mathrm{~cm}$ and the maximum clear zone diameter of 2.5 $\mathrm{cm}$ was observed in PSB7 followed by PSB1 (2.1) and PSB5(2.52) and the least clear zone was obtained in PSB4
(1.1) (Table 2). Likewise, results from solubilization index (SI) indicated that PSB7 (3.50) ranked first followed by PSB1 (2.61) and PSB5. But isolate PSB4 (1.80) was with the least solubilization index.

The solubilization index of the isolates ranged from 1.80 to $3.50 \mathrm{~cm}$ at five days after incubation. Among the isolates PSB4 showed maximum solubilization zone $(3.50 \mathrm{~cm}$ diameter) followed by PSB1 $(2.61 \mathrm{~cm})$ and PSB5 $(2.52 \mathrm{~cm})$. However, the isolate PSB7 showed the least solubilization zone of $1.80 \mathrm{~cm}$ diameter.

\subsection{Quantitative Estimation of P Solubilizing Activity of the Isolates from Different Phosphate Sources}

The amount of $\mathrm{P}$ released from tricalcium phosphate, rock phosphate and bone phosphate in a broth by the isolates was studied at 5, 10, 15 days after incubation (DAI).

Tricalcium phosphate solubilization efficiency of isolates.

Table 3. Results on tricalcium phosphate solubilization efficiency of isolates upon 15 days of incubation.

\begin{tabular}{|c|c|c|c|c|c|c|}
\hline \multirow{2}{*}{ Isolates } & \multicolumn{2}{|c|}{$5^{\text {th }}$ day } & \multicolumn{2}{|c|}{$10^{\text {th }}$ day } & \multicolumn{2}{|c|}{$15^{\text {th }}$ day } \\
\hline & pH & $P \mathrm{mg} / 50 \mathrm{ml}$ & $p^{H}$ & $P \mathrm{mg} / 50 \mathrm{ml}$ & $p^{H}$ & $\mathrm{P} \mathrm{mg} / \mathbf{5 0 \mathrm { ml }}$ \\
\hline PSB1 & 6.82 & $7.642 \pm 0.347^{\mathrm{a}}$ & 5.25 & $8.103 \pm 0.660^{\mathrm{a}}$ & 5.89 & $10.396 \pm 0.802^{b}$ \\
\hline PSB2 & 6.60 & $6.428 \pm 0.440^{\mathrm{b}}$ & 5.67 & $8.195 \pm 1.019^{\mathrm{a}}$ & 5.46 & $11.337 \pm 1.042^{\mathrm{a}}$ \\
\hline PSB4 & 6.60 & $4.792 \pm 0.345^{\mathrm{c}}$ & 5.49 & $5.974 \pm 0.223^{b}$ & 6.28 & $6.694 \pm 0.270^{\mathrm{c}}$ \\
\hline PSB5 & 6.57 & $4.98 \pm 0.415^{\mathrm{c}}$ & 6.10 & $5.266 \pm 0.485^{\mathrm{b}}$ & 6.13 & $5.440 \pm 0.253^{\mathrm{d}}$ \\
\hline PSB7 & 6.29 & $6.471 \pm 0.875^{\mathrm{b}}$ & 5.70 & $7.558 \pm 0.425^{\mathrm{a}}$ & 5.22 & $11.772 \pm 0.175^{\mathrm{a}}$ \\
\hline Control & 7.64 & $2.201 \pm 0.100^{\mathrm{d}}$ & 7.61 & $2.558 \pm 0.152^{c}$ & 7.58 & $2.94 \pm 0.427^{\mathrm{e}}$ \\
\hline
\end{tabular}

Note: All values are means of triplicates \pm SD. Levels not connected by same letter under the same column are significantly different ( $\leq 0.05$ ) using JMP method of analysis.

The results of tricalcium phosphate solubilization by the selected isolates and the associated $\mathrm{pH}$ changes in the medium are shown Table 3. All bacterial isolates solubilized significantly $(\mathrm{P}<0.05)$ higher amounts of tricalcium phosphate over uninoculated control. The results on Table 4 indicated that the P released from TCP by the strain at 15 days after inoculation ranged from $5.44 \mathrm{mg} / 50 \mathrm{ml}$ to 11.77 $\mathrm{mg} / 50 \mathrm{ml}$. The result showed that PSB7 $(11.77 \mathrm{mg} / 50 \mathrm{ml})$ was found to be more efficient in solubilizing tricalcium phosphate than the rest of the isolates at $15^{\text {th }}$ days of incubation. But the amount of $\mathrm{P}$ released from each isolate is different at each period of incubation. The highest $p$ release upon 5 days of incubation was recorded from the isolate PSB1 with $7.64 \mathrm{mg}$ per $50 \mathrm{ml}$ in the medium followed by isolate PSB2 that released $6.4 \mathrm{mg}$ per $50 \mathrm{ml}$. But the least $\mathrm{P}$ release was recorded by isolates PSB4 and PSB5 with a $\mathrm{P}$ content of $4.79 \mathrm{mg} / 50 \mathrm{ml}$ and $4.98 \mathrm{mg} / 50 \mathrm{ml}$ at $\mathrm{pH}$ 7.6. At $10^{\text {th }}$ day of incubation, the highest $\mathrm{P}$ release was recorded by isolates PSB2 $(8.19 \mathrm{mg} / 50 \mathrm{ml})$, followed by PSB4 $(5.974 \mathrm{mg} / 50 \mathrm{ml})$ and PSB5 $(5.26 \mathrm{mg} / 50 \mathrm{ml})$. At $15^{\text {th }}$ days of incubation, the highest $\mathrm{P}$ release was recorded by isolate PSB7 (11.77) followed by PSB1 (10.39 mg/ 50ml). The least $P$ release was recorded by isolate PSB5 $(5.44 \mathrm{mg} / 50 \mathrm{ml})$.

Regarding $\mathrm{pH}$, there was a drop of $\mathrm{pH}$ in incubation times of 5 to 15 days. However, the pattern of drop was not constant and $\mathrm{pH}$ drop was observed in all isolates. The $\mathrm{pH}$ drop was drastic starting from the $5^{\text {th }}$ day to the $15^{\text {th }}$ days of incubation. Accordingly, at the 15 days of incubation, the maximum drop of $\mathrm{pH}$ was observed at isolate PSB2 (2.14) followed by PSB7 (2.07) and the least pH drop was observed at PSB1 (0.93).

Egyptian Rock Phosphate (EGP) Solubilizing Efficiency of Isolates.

Table 4. Egyptian rock phosphate solubilizing efficiency of isolates upon 15 days of incubation.

\begin{tabular}{|c|c|c|c|c|c|c|}
\hline \multirow{2}{*}{ Isolates } & \multicolumn{2}{|c|}{$5^{\text {th }}$ day } & \multicolumn{2}{|c|}{$10^{\text {th }}$ day } & \multicolumn{2}{|c|}{$15^{\text {th }}$ day } \\
\hline & $\mathbf{P}^{\mathrm{H}}$ & P mg/50ml & $\mathbf{P}^{\mathrm{H}}$ & $P \mathrm{mg} / 50 \mathrm{ml}$ & $\mathbf{P}^{\mathrm{H}}$ & P mg/50ml \\
\hline PSB1 & 5.74 & $3.694 \pm 1.489^{\mathrm{a}}$ & 4.37 & $4.383 \pm 1.11^{b c}$ & 3.63 & $4.714 \pm 1.273^{\mathrm{cd}}$ \\
\hline PSB2 & 6.13 & $3.701 \pm 0.264^{\mathrm{a}}$ & 4.59 & $4.077 \pm 0.55^{\mathrm{bc}}$ & 3.61 & $5.363 \pm 0.739^{c}$ \\
\hline PSB4 & 5.68 & $3.324 \pm 1.048^{\mathrm{ab}}$ & 4.37 & $3.467 \pm 0.88^{\mathrm{cd}}$ & 3.80 & $4.025 \pm 0.725^{\mathrm{d}}$ \\
\hline PSB5 & 6.04 & $3.240 \pm 0.341^{\mathrm{ab}}$ & 4.40 & $5.564 \pm 0.645^{\mathrm{a}}$ & 3.54 & $6.883 \pm 0.232^{\mathrm{b}}$ \\
\hline PSB7 & 6.22 & $3.660 \pm 0.225^{\mathrm{a}}$ & 4.87 & $5.025 \pm 0.87^{\mathrm{ab}}$ & 3.16 & $7.928 \pm 0.440^{\mathrm{a}}$ \\
\hline Control & 6.82 & $2.105 \pm 0.360^{b}$ & 6.78 & $2.158 \pm 0.370^{\mathrm{d}}$ & 6.62 & $2.34 \pm 0.173^{\mathrm{e}}$ \\
\hline
\end{tabular}

Note: All values are means of triplicates \pm SD. Levels not connected by same letter under the same column are significantly different ( $\leq 0.05$ )) using JMP method of analysis. 
There was significant $(\mathrm{P} \leq 0.05)$ solubilization of (EGP) over the uninoculated control by the five isolates. The amount of soluble phosphate and the corresponding $\mathrm{pH}$ change of the medium is presented in Table 4. The solubilization increased steadily up to 15 days of incubation where the maximum amount of soluble phosphorus was released. The results indicated that the $\mathrm{P}$ released from ERP by the isolate at 15 days after inoculation ranged from 4.025 $\mathrm{mg} / 50 \mathrm{ml}$ to $7.928 \mathrm{mg} / 50 \mathrm{ml}$. The $\mathrm{P}$ released from all isolates upon 5 days of incubation was not significant as compared to the control. At $10^{\text {th }}$ day of incubation, the highest $\mathrm{P}$ release was recorded by isolates PSB5 $(5.56 \mathrm{mg} / 50 \mathrm{ml})$, and followed by PSB1 $(4.38 \mathrm{mg} / 50 \mathrm{ml})$ and the least $P$ release was observed by isolate PSB4 $(3.467 \mathrm{mg} / 50 \mathrm{ml})$. At $15^{\text {th }}$ days of incubation, the highest $\mathrm{P}$ release was recorded by isolate PSB7 $(7.928 \mathrm{mg} / 50 \mathrm{ml})$ followed by PSB5 $(6.88 \mathrm{mg} / 50 \mathrm{ml})$ and the least $\mathrm{P}$ release was recorded by isolate PSB4 $(4.025 \mathrm{mg} / 50 \mathrm{ml})$.

Regarding $\mathrm{pH}$, there was a drop of $\mathrm{pH}$ in incubation times of 5 to 15 with different variations. The total $p^{\mathrm{H}}$ drop was estimated for each isolates. Accordingly, the maximum drop of $\mathrm{pH}$ was observed at isolate PSB7 (3.06) followed by PSB2 (2.52) and PSB5 (1.44) and the least $\mathrm{pH}$ drop was observed at PSB4 (1.88) (table 4).

Bone phosphate solubilizing efficiency of the isolates

Table 5. Bone phosphate solubilizing efficiency of the isolates upon 15 days of incubation.

\begin{tabular}{|c|c|c|c|c|c|c|}
\hline \multirow{2}{*}{ Isolates } & \multicolumn{2}{|l|}{$5^{\text {th }}$ day } & \multicolumn{2}{|l|}{$10^{\text {th }}$ day } & \multicolumn{2}{|c|}{$15^{\text {th }}$ day } \\
\hline & pH & P mg/50ml & pH & P mg/50ml & pH & P mg/50ml \\
\hline PSB1 & 5.83 & $4.500 \pm 0.278^{a}$ & 4.39 & $6.058 \pm 0.530^{\mathrm{bc}}$ & 3.78 & $9.120 \pm 0.361^{\mathrm{c}}$ \\
\hline PSB2 & 5.25 & $4.290 \pm 0.486^{\mathrm{a}}$ & 4.33 & $5.47 \pm 0.430^{c}$ & 3.58 & $10.461 \pm 0.373^{b}$ \\
\hline PSB5 & 6.13 & $3.935 \pm 0.199^{\mathrm{a}}$ & 4.35 & $7.370 \pm 0.330^{\mathrm{a}}$ & 3.79 & $10.974 \pm 0.373^{b}$ \\
\hline PSB7 & 5.57 & $3.020 \pm 0.193^{\mathrm{b}}$ & 4.38 & $7.025 \pm 0.252^{\mathrm{a}}$ & 3.67 & $11.093 \pm 0.491^{\mathrm{a}}$ \\
\hline Control & 6.45 & $0.480 \pm 0.223^{\mathrm{c}}$ & 6.33 & $0.62 \pm 0.127^{\mathrm{d}}$ & 6.17 & $0.66 \pm 0.126^{\mathrm{d}}$ \\
\hline
\end{tabular}

Note: All values are means of triplicates \pm SD. Levels not connected by same letter under the same column are significantly different ( $\leq 0.05$ ) using JMP method of analysis.

The amount of soluble phosphate released from the bone phosphate and corresponding $\mathrm{pH}$ decrease of the medium by the PSB isolate is shown in Table 5. The maximum solubilization was achieved at 15 days of incubation with different variations of each incubation days. The P released from all isolates except isolate PSB7 $(3.020 \mathrm{mg} / 50 \mathrm{ml})$ upon 5 days of incubation was not significant as compared to the control. At $10^{\text {th }}$ day of incubation, the highest $\mathrm{P}$ release was recorded by isolates PSB5 $(7.37 \mathrm{mg} / 50 \mathrm{ml})$ followed by PSB4 $(6.31 \mathrm{mg} / 50 \mathrm{ml})$ and the least $\mathrm{P}$ release was observed by isolate PSB2 $(5.47 \mathrm{mg} / 50 \mathrm{ml})$. At $15^{\text {th }}$ days of incubation, the highest P release was recorded by isolate PSB7 (11.09 mg/ $50 \mathrm{ml})$ followed by PSB5 (10.974 $\mathrm{mg} / 50 \mathrm{ml})$ and PSB2 $(10.46 \mathrm{mg} / 50 \mathrm{ml})$. The least $\mathrm{P}$ release was recorded by isolate PSB4 $(9.06 \mathrm{mg} / 50 \mathrm{ml})$. Among the isolates PSB7 released maximum amount of P from BP $11.093 \mathrm{mg} / 50 \mathrm{ml}$ followed by PSB5 $10.974 \mathrm{mg} / 50 \mathrm{ml}$. On the contrary, there was a drastic pHdrop from 5 to 15 days of incubation. The highest $\mathrm{pH}$ drop was observed on PSB5 (2.34), followed by PSB1 (2.05) and PSB7 (1.90) and the least pH drop was observed on PSB4 (1.43). Unlike the tricalcium phosphate and rock phosphate, the amount of phosphorus released by different isolates of PSB on the bone phosphate as a function of time was not significant (Table 5).

\section{Discussion}

In the present study five phosphate solubilizing bacteria designated as PSB1, PSB2 PSB4, PSB5, and PSB7 were isolated from soil samples collected from tomato growing farmer's fields in Debrezeit district (Bishoftu). The isolates were found to be non spore formers, gram negative, rod shaped, oxidase and catalase positive, pigment producers (yellow and greenish blue), gelatinase negative, starch hydrolysis positive and lactose, maltose and dextrose carbon source utilizers and they were all found to belong to the genus Pseudomonas. This finding is similar to earlier reports that stipulate that most efficient and frequently encountered phosphate solubilizing bacteria belonging to the genus Pseudomonas or the genus Bacillus [25]. The researcher [10] also isolated phosphate solubilizing bacteria of the genus Pseudomonas from rhizosphere of faba bean in northern part of Ethiopia.

When grown in culture media supplemented with Tricalcium phosphate, all isolates produced halo zone around the colonies, indicating the solubilization of phosphate source used. Phosphate solubilizing microbes are detected by the formation of clear halos around their colonies [18]. Based on halo zone formation around their colonies and their solubilization index, isolates showed variations in that the most effective isolate was PSB7 with SI value of 3.5 followed by PSB1, PSB5 with SI of 2.61, 2.52 respectively (Table 2 ).

All isolates were confirmed for their $\mathrm{P}$ solubilization ability on TCP, ERP and BP by using phospho- molybdate test. All PSB isolates solubilized significantly greater amount of TCP, RP, and BP over uninoculated control (tables 3, 4, 5).

In the present study there was a progressive increase in the solubilization of TCP by all PSB isolates. The maximum release of $\mathrm{P}$ was observed at $15^{\text {th }}$ of incubation period by PSB7 followed by PSB2 with phosphate content of 11.77 $\mathrm{mg} / \mathrm{g}$ and $11.33 \mathrm{mg} / \mathrm{g}$ respectively. This result is in agreement with [11] that the solubilization of TCP (Table 3) was progressive and maximum at 15 of days of incubation with the maximum release of $6.3 \mathrm{mg} / 50 \mathrm{ml}$. [26] also reported that the maximum $\mathrm{P}$ solubilization was recorded at the last days 
by Arthrobacter sp. (CC-BC03) $(22.09 \mathrm{mg} / 50 \mathrm{ml})$ with a maximum drop in the $\mathrm{pH}$ to 4.9 .

The solubilization of Egyptian rock phosphate with the isolates continued up to 15 days with maximum solubilization by PSB7 $(7.92 \mathrm{mg} / 50 \mathrm{ml})$ followed by PSB5 $(6.88 \mathrm{mg} / 50 \mathrm{ml})$ (table 3). Similarly, [11] reported that the maximum solubilization was observed by isolate AUAL-6 at the fifteenth day of inoculation with phosphate release of $16.5 \mathrm{mg} / 50 \mathrm{ml}$. The paper [27] also reported that Actinobacteria strains showed different abilities to release soluble phosphate from ERP. According to him strain AT12 was the most efficient strain releasing $25.87 \mu \mathrm{g} / \mathrm{ml}$ soluble $\mathrm{P}$ in the growth medium.

Similarly the trend of bone phosphate solubilization by the isolates was progressive up to 15 days of incubation. As in the case of TCP and ERP, PSB7 released the maximum $p$ in BP. This result was in contrary with the report of the researcher [28] who reported that Jim41was the most efficient solubilization in TCP and RP but least in solubilizing bone phosphate. This variation may be due to the efficiency of the isolate PSB7. The presence of small amount of soluble phosphorus in the uninoculated control flask in all solubilization tests is assumed to be due to the release of phosphate ions during autoclaving [28].

In all cases of phosphorus source solubilization, there was inverse relationship between release of soluble phosphorus and reduction in the $\mathrm{pH}$ of the medium for all substrates. The highest soluble phosphorus in tricalcium phosphate was observed with PSB7 $(11.77 \mathrm{mg} / 50 \mathrm{ml})$ and PSB2 $(11.33 \mathrm{mg} / 50 \mathrm{ml})$ with the corresponding $\mathrm{pH}$ drop of 2.07 , 2.14 during 15 days of incubation respectively (table 4). Similarly, Paul and the study [29] revealed that there was a perfect inverse correlation with the amounts of tricalcium solubilized and the $\mathrm{pH}$ of the medium inoculated with PSB cultures. Among twelve PSBs tested, the highest amount of tricalcium phosphate solubilization was achieved by Bacillus brevis with the lowest $\mathrm{pH}$ of 4.4. Acid production and reduction of the $\mathrm{pH}$ of the medium is one of the mechanisms by which soluble phosphorus is released by PSB (Gaur, 1999).

The drop in $\mathrm{pH}$ of the inoculated medium containing Egyptian rock phosphate was more drastic than tricalcium phosphate and bone phosphate. Among the different phosphorus sources tested, the lowest $\mathrm{pH}$ (acidic) pattern value was observed in rock phosphate inoculated with PSB7 isolate. According to the studies [26] and [10] this could be due to the high insolubility of Egyptian rock phosphate compared to tricalcium phosphate. Thus, some PSB isolates when inoculated in a medium with Egyptian rock phosphate released more acid than they did with tricalcium phosphate.

In the present study an inverse relationship between $\mathrm{pH}$ and soluble phosphate concentration was observed among all the isolates. In this study, a drastic drop in $\mathrm{pH}$ was observed in all treatments in opposite to the phosphorus amount released (tables 3, 4, 5). This was due to the fact that phosphate solubilization by different PSBs is involved with the production of organic acids [27]. Similar inverse relationship between $\mathrm{pH}$ and soluble phosphate was reported earlier by the study [28]. The P-solubilizing activity is determined by the microbial biochemical ability to produce and release organic acids, which through their carboxylic groups chelate the cations (mainly $\mathrm{Ca}$ ), bound to phosphate converting them into the soluble forms [29].

\section{Conclusion}

In the present study five phosphate solubilizing bacteria coded as PSB1, PSB2, PSB4, PSB5 and PSB7 were isolated and characterized under genus Pseudomonas. All isolates were found to be efficient in solubilization of tricalcium phosphate, Egyptian rock phosphate, and bone phosphate. However, except PSB7 which solubilized maximum in all phosphate sources, there was variation of solubilization efficiency among other isolates. This fact may be due to the mechanisms employed to solubilize, species difference and other environmental factors. The maximum amount of soluble $\mathrm{P}$ was released by PSB isolates from tricalcium phosphate, followed by bone phosphate and Egyptian rock phosphate. So, in conclusion Pseudomonas was found to be effective in releasing phosphate from inorganic and organaic phosphate soureces.

\section{References}

[1] Role of soil microorganisms in improving $\mathrm{P}$ nutrition of plants. Plant and soil, 245 (1) (2002), 83-93.

[2] Phosphate-solubilization activity of bacterial strains in soil and their effect on soybean growth under greenhouse conditions. Biology and Fertility of Soils, 43 (6) (2007), 805-809.

[3] Evaluation of the capacity of phosphate solubilizing bacteria and fungi on different forms of phosphorus in liquid culture. Journal of Sustainable Agriculture, 28 (3) (2006). 99-108.

[4] Phosphorus solubilizing bacteria: occurrence, mechanisms and their role in crop production. J agricbiolsci, 1 (1) (2009), 4858 .

[5] Interactive effect of rhizotrophic microorganisms on yield and nutrient uptake of chickpea (Cicer arietinum L.). European journal of agronomy, 19 (1) (2003), 15-21.

[6] AEffect of metal tolerant plant growth promoting Bradyrhizobium sp.(vigna) on growth, symbiosis, seed yield and metal uptake by greengram plants. Chemosphere, 70 (1) (2007), 36-45.

[7] Effect of bradyrhizobia and phosphate solubilizing bacteria application on Soybean in rotational system in the Mekong delta. Omonrice, 14, (2006), 48-57.

[8] Root elongation in various agronomic crops by the plant growth promoting rhizobacterium Pseudomonas putida GR12-2. Israel Journal of Plant Sciences, 44 (1) (1996), 3742.

[9] Isolation of phosphate solubilizing bacteria from the rhizosphere of faba bean of Ethiopia and their abilities on solubilizing insoluble phosphates. J. Agric. Sci. Technol, 12 (2010), 79-89. 
[10] Phenotypic and Symbiotic Characterization of Efficient Phosphate Solubilizing Bacteria from Lentil Nodulating Rhizobium and Rhizospheric Soil from Some Ethiopian Soils. Msc. Thesis, Addis Ababa University, Ethiopia, (2009).

[11] Phosphate-solubilising rhizobacteria associated with Coffea arabica L. in natural coffee forests of southwestern Ethiopia. Journal of the Saudi Society of Agricultural Sciences, 12 (1) (2013), 73-84.

[12] Phenotypic diversity and plant growth promoting characteristics of Mesorhizobium species isolated from chickpea (Cicer arietinum L.) growing areas of Ethiopia. African Journal of Biotechnology, 11 (29) (2012).

[13] Growth promotion of common bean (Phaseolus vulgaris L.) by a strain of Burkholderia cepacia under growth chamber conditions. Soil Biology and Biochemistry, 33 (14) (2001), 1927-1935.

[14] In vitro production of growth regulators and phosphatase activity by phosphate solubilizing bacteria. African Journal of Biotechnology, 5 (4) (2006), 348-350.

[15] Diversity of fungal endophytes in shrubby medicinal plants of Malnad region, Western Ghats, Southern India. fungal ecology, 1 (2-3) 2008), 89-93.

[16] Indole acetic acid production and enhanced plant growth promotion by indigenous PSBs. African Journal of Agricultural Research, 4 (11) (2009).1312-1316.

[17] Effect of plant growth promoting rhizobacteria on seed germination and plant growth chickpea (Cicer arietinum L.) under in vitro conditions. In Biological Forum 2:2, (15-18) (2010).

[18] Mobilization of phosphorus in soil in connection with vital activity of some microbial species. Mikrobiologiya, 17 (1948), 362-370.

[19] Experiments in microbiology, plant pathology and biotechnology. New Age International. (2007).
[20] Visible spectral reflectance measurements $(0.33-1.1 \mu \mathrm{m})$ of the Galilean satellites at many orbital phase angles. Icarus, 44 (2) (1980), 410-430.

[21] The oxidase reaction as a taxonomic tool. Microbiology, 25 (2), 297-306.

[22] Drop-size spectra and deposits of four Bacillus thuringiensis formulations on simulated and natural fir foliage. Transactions of the ASAE, 37 (1) (1961), 9-17.

[23] Streptomyces youssoufiensis sp. nov., isolated from a Moroccan phosphate mine. International journal of systematic and evolutionary microbiology, 61 (5) (2011), 1104-1108.

[24] Isolation and Characterization of Phosphate solublizing bacteria from Some Ethiopian Soils and their Effect on the Growth of Faba Bean (Doctoral dissertation, M. Sc. Thesis, Addis Ababa University, Addis Ababa. (1999).

[25] Isolation and characterisation of phosphate solubilising microorganisms from the cold desert habitat of Salix alba Linn. in trans Himalayan region of Himachal Pradesh, Indian J. Microbiol, 48 (2008), 267-273

[26] Phosphate solubilizing microorganisms-An overview. Current trends in life sciences, Today and tomorrows publishers, New Delhi. (1999).

[27] On-farm seed priming reduces yield losses of mungbean (Vignaradiata) associated with mungbean yellow mosaic virus in the North West Frontier Province of Pakistan. Crop Protection, 23 (11) (2004), 1119-1124.

[28] 2-Ketogluconic acid production and phosphate solubilization by Enterobacterintermedium. Current microbiology, 47 (2) (2003), 0087-0092.

[29] Effect of organic acids on release of phosphorus from phosphate rocks. Soil Science, 158 (6) (1994), 442-453. 